\title{
A Comparison of Two Immediate-Early Genes, c-fos and NGFI-B, as Markers for Functional Activation in Stress-related Neuroendocrine Circuitry
}

\author{
R. K. W. Chan, E. R. Brown, A. Ericsson, K. J. Kovács, and P. E. Sawchenko \\ Laboratory of Neuronal Structure and Function, The Salk Institute, and The Foundation for Medical Research, San Diego, \\ California 92186-5800
}

The promoter regions of the rat corticotropin-releasing factor (CRF), oxytocin (OT), and vasopressin (AVP) genes contain sequences similar to the cis-acting response element identified for NGFI-B, an immediate-early gene structurally related to the steroid hormone receptor superfamily. Combined immuno- and hybridization histochemical approaches were used to determine whether challenges that influence the synthesis and secretion of CRF, OT, and/or AVP result in altered expression in neurosecretory neurons of NGFI-B and another immediate-early gene, $c$-fos, which is widely used as a marker for functionally activated neurons. NGFI-B mRNA was found to be expressed at constitutively high levels in the telencephalon, but not in the endocrine hypothalamus, of unperturbed controls; basal levels of c-fos expression were uniformly low throughout the CNS. NGFI-B and c-fos mRNAs, and Fos protein, were induced with a similar time course and in similar neuroendocrine cell types in response to acute hypotensive hemorrhage $(15 \%$ reduction in blood volume), intravenous injection of interleukin- $1 \beta$ (IL-1 $\beta ; 1.87$ $\mu \mathrm{g} / \mathrm{kg}$ ), chronic salt loading (7 d maintenance on $2 \%$ saline), and acute bilateral adrenalectomy. c-fos mRNA and Fos protein were readily demonstrable in afferent pathways that have been implicated as mediating the neuroendocrine responses in the three stress paradigms; these include medullary catecholaminergic cell groups in response to IL-1 $\beta$ and hemorrhage, and cell groups lining the lamina terminalis in response to salt loading. Challenge-specific induction of NGFI-B expression was detectable in these extrahypothalamic cell groups, though with a lesser sensitivity than that required to reveal NGFI-B induction in the hypothalamus, or c-fos expression in these related afferents. These results establish NGFI-B as a useful adjunct to c-fos, for revealing

\footnotetext{
Received Apr. 12, 1993; revised May 25, 1993; accepted June 2, 1993.

This work was supported by NIH Grants NS-21182 (ADX, IL-1, salt-loading models) and HL-35137 (hemorrhage model), and was conducted in part by the Foundation for Medical Research. P.E.S. is an Investigator of the Foundation for Medical Research. Fellowship support was provided by the American Heart Association-California Affiliate (R.K.W.C.), the Xerox Foundation (E.R.B.), the Fogarty Foundation and Swedish Medical Research Council (A.E.), and IRFX (K.J.K.). The contribution of all authors should be considered equal. We are grateful to Drs. J. Milbrandt, T. Curran, and K. Mayo for providing plasmids, Dr. S. Gillis of the Immunex Corporation for recombinant human IL-1 $\beta$, Dr. Catherine Rivier for RIA of plasma corticosterone, and Kris Trulock and Carlos Arias for excellent assistance in the preparation of figures and histological material, respectively.

Correspondence should be addressed to Dr. P. E. Sawchenko, The Salk Institute, P.O. Box 85800, San Diego, CA 92186.

Copyright (C) 1993 Society for Neuroscience $0270-6474 / 93 / 135126-13 \$ 05.00 / 0$
}

synaptic and/or transcriptional activation in the magno- and parvocellular neurosecretory systems. Differences in the sensitivity of the two markers in revealing functionally related activation in extrahypothalamic regions speak to general issues concerning the use of immediate-early genes in mapping functional circuitry in the CNS.

[Key words: c-fos, corticotropin-releasing factor, hypothalamus, NGFI-B, oxytocin, paraventricular nucleus, stress, vasopressin]

The validation of c-fos as an inducible and widely applicable marker for neural systems activated by a variety of extracellular stimuli has provided a means to identify cell groups that may be linked into functional circuits in a situation-specific manner (Sagar et al., 1988; for reviews, see Morgan and Curran, 1989, 1991). The power of this method has been particularly evident in central neuroendocrine systems, where effector neurons are relatively well demarcated at the anatomical and neurochemical levels. The study of central stress-related circuitries, among others, has already profitted from the advent of this approach (e.g., Ceccatelli et al., 1989; Jacobson ct al., 1990; Badoer et al., 1992; Hamamura et al., 1992).

Parvocellular neurosecretory neurons, localized to a relatively discrete aspect of the paraventricular nucleus of the hypothalamus (PVH), are acknowledged as the principal source of corticotropin-releasing factor (CRF) in hypophyseal-portal plasma for the stimulatory control of stress-induced adrenocorticotropic hormone secretion (Antoni, 1986; Sawchenko and Swanson, 1990). This population also has the capability to express additional peptides, notably arginine vasopressin (AVP), that either independently or via interaction with CRF are stimulatory to anterior pituitary corticotropes (Rivier and Vale, 1983). Magnocellular neurosecretory neurons, the principal sources of circulating AVP and oxytocin (OT), appear to contribute to the high concentrations of both nonapeptides in hypophyseal portal plasma (Holmes et al., 1986; Antoni et al., 1990). The mechanisms that provide for such interactions between neurosecretory cell types remain to be fully characterized. The central limb of the hypothalamo-pituitary-adrenal (HPA) axis is regulated negatively by circulating corticosteroids (Keller-Wood and Dallman, 1984; Swanson and Simmons, 1989) and positively by stress (for review, see Harbuz and Lightman, 1992); both influences appear to be exerted at both the biosynthetic and secretory levels (Plotsky, 1991), and both have been shown to be accompanied by induction of c-fos mRNA and/or Fos protein ex- 
pression in parvocellular neurons (Ceccatelli et al., 1989; Jacobson et al., 1990; Badoer et al., 1992; Herman et al., 1992; Imaki et al., 1992). Attention has now begun to turn toward an examination of patterns of stimulation-induced extrahypothalamic Fos expression in order to specify potential afferents that may convey stress- or steroid-related information to the endocrine hypothalamus (Badoer et al., 1992; Giovannelli and Bloom, 1992; Hamamura et al., 1992), and to an examination of the role that Fos may play in mediating stimulus-transcription coupling in hypothalamic neurons (e.g., Herman et al., 1992; Imaki et al., 1992).

c-fos is a cellular immediate-early gene (cIE) whose protein product, Fos, dimerizes with nuclear proteins encoded by members of the c-jun gene family to interact with a specific cis-acting DNA sequence, the AP-1 site, to regulate transcription (Chiu et al., 1988; Curran and Franza, 1988; Morgan and Curran, 1991). While Fos has been shown to be induced in parvocellular neurosecretory CRF neurons in response to stress, it appears unlikely that the multiple transcriptional response elements contained within the CRF promoter (Seasholtz et al., 1988; Thompson et al., 1990) include a functional AP-1 site. This would suggest that Fos is not directly involved in stress-induced alterations in CRF expression. Moreover, although Fos has come to be widely used as a marker for neuronal activation, it is as yet unclear whether the capacity for c-fos expression is universal among central neurons, or whether functionally related cells necessarily induce any given cIE with roughly equivalent sensitivities (Dragunow and Faull, 1989: Bullitt, 1990). In fact, a lack of a consistent relationship between Fos induction and neuronal activity has been reported in some parts of the CNS (e.g., Labiner et al., 1993). Thus, reliance on a single clE marker of functional activity may be misleading. In light of these considerations, a broad-based test of the generality with which c-fos and additional cIEs may serve as reliable activity markers in neuronal systems of interest would seem warranted. Therefore, we have investigated whether NGFI-B (Milbrandt, 1988; Watson and Milbrandt, 1989), an alternative cIE, might serve as a useful marker, relative to Fos, for functional mapping of stressrelated hypothalamic neuroendocrine neurons and their afferents in response to a variety of established treatment paradigms.

NGFI-B [also known as nur77, N10, and TISI in mice (Hazel et al., 1988, 1991); NAK1 in human (Nakai et al., 1990)] was isolated and characterized from PC1 2 cells as a cIE induced by treatment with nerve growth factor (Milbrandt, 1988; Watson and Milbrandt, 1989). It is structurally related to the steroid hormone receptor superfamily, a class of ligand-dependent transcriptional activator proteins (Evans, 1988). A potential response element for NGFI-B has been noted within the $5^{\prime}$ promoter region of the rat CRF gene (Wilson et al., 1991, 1993), and similar sequences are found in the AVP and OT promoters (see Discussion). Thus, there exists an a priori basis for considering NGFI-B as a potential marker for stress-related neuroendocrine neurons. In the present study, combined immuno- and in situ hybridization histochemical approaches were used to determine whether physiologically well-established challenges, including bilateral adrenalectomy, acute hypotensive hemorrhage, intravenous infusion of interleukin- $1 \beta(\mathrm{IL}-1 \beta)$, and chronic salt loading, result in comparable alterations in c-fos and NGFI-B expression in hypothalamic neurosecretory neurons and some potentially related afferent pathways.

Portions of these data have been reported in abstract form (Brown et al., 1992; Ericsson et al., 1992).

\section{Materials and Methods}

Animals. Adult male Sprague-Dawley albino rats (250-320 gm) were housed individually in a temperature-controlled room on a $12: 12 \mathrm{hr}$ light/dark cycle (lights on at 0600), with food and water freely available. Animals to be subjected to acute stress (hemorrhage, IL-1 $\beta$ injection) were handled daily for 5-7 d prior to experimentation. Separate groups of experimental and control rats were exposed to one of four distinct challenges known to target hypothalamic stress-related neurons. These included two acute stresses (hemorrhage, systemic IL- $1 \beta$ injection), one chronic challenge (salt loading), and one involving manipulation of the steroid environment (adrenalectomy). All protocols were approved by the Institutional Animal Care and Ise Committee

Interleukin-I injection. Two days prior to IL- $1 \beta$ administration, a catheter (PE-50) containing sterile, pyrogen-free heparin-saline $(500$ $\mathrm{U} / \mu \mathrm{l})$ was implanted in the jugular vein of methoxyflurane-anesthetized rats. The sealed catheter was positioned with its internal Silastic tip at the atrium and was exteriorized at an interscapular position. On the day of experimentation, the jugular catheter was connected to a remote cannula and IL- $1 \beta$ injections $(n=10)$ were performed $3 \mathrm{hr}$ after connection. Recombinant human IL- $1 \beta\left(1 \times 10^{8} \mathrm{U} / \mathrm{mg}\right.$ in the $\mathrm{A} 375$ assay, $17 \mathrm{ng}$ endotoxin/mg protein; kindly provided by Dr. S. Gillis, Immunex Corp.) at a dose of $1.87 \mu \mathrm{g} / \mathrm{kg}$, diluted in $300 \mu \mathrm{l}$ of sterile buffer containing $0.01 \%$ bovine serum albumin (BSA), $70 \mathrm{~mm}$ Tris (pH 7.4 at room temperature), and $0.01 \%$ ascorbic acid, was injected intravenously over a period of $3 \mathrm{~min}$. Control rats $(n=6)$ were infused with a similar volume of vehicle. Injections were timed so that rats were killed consistently between 1300 and 1400 .

Hemorrhage. Animals $(n=30)$ were implanted with jugular catheters as described above, and hypotensive hemorrhage was induced by withdrawal of $12 \mathrm{ml} / \mathrm{kg}$ blood (an estimated $15 \%$ blood loss) in $3 \mathrm{~min}$ via the indwelling catheter. Control rats $(n=20)$ were prepared and manipulated similarly until the point of bleeding. Animals were anesthetized for perfusion at $0.5 \mathrm{hr}$ intervals up to $4 \mathrm{hr}$ between 0830 and 1200 following hemorrhage.

Salt loading. Salt loading simply involved maintaining a group of animals $(n=7)$ on $2 \%$ saline as the sole source of fluids for $7 \mathrm{~d}$; a control group $(n=6)$ received tap water. Rats were killed on the morning of the seventh day of exposure.

Adrenalectomy. Bilateral adrenalectomy (ADX; $n=13$ ) was carried out between 0800 and 1200 under methoxyflurane anesthesia via incisions in the dorsolateral flanks. Twelve sham-operated animals provided comparisons. All rats were allowed a choice of either water or $0.9 \%$ saline to drink throughout postoperative survival periods. Rats were killed at 3,6 , or $12 \mathrm{hr}$ after surgery. Blood samples were collected from the atria at the time of perfusion and plasma corticosterone concentrations determined by radioimmunoassay as previously described (Rivest and Rivier, 1991). The limit of detection of the assay was 0.87 $\mathrm{ng} / \mathrm{ml}$, with inter- and intra-assay coefficients of variation of $3.7 \%$ and $2.2 \%$, respectively. Corticosterone titers were reduced in animals killed at $3 \mathrm{hr}$ after ADX, and beneath the sensitivity of the assay in animals killed at 6 or $12 \mathrm{hr}$ after ADX.

Histology. Animals were deeply anesthetized with chloral hydrate (35 $\mathrm{mg} / \mathrm{kg}$, i.p.) and perfused via the ascending aorta with saline followed by $500-700 \mathrm{ml}$ of ice-cold $4 \%$ paraformaldehyde in $0.1 \mathrm{M}$ borate buffer (pH 9.5 at $10^{\circ} \mathrm{C}$ ). Brains were postfixed for $3-4 \mathrm{hr}$, and then cryoprotected in $10 \%$ sucrose in $0.1 \mathrm{~m}$ phosphate buffer overnight at $4^{\circ} \mathrm{C}$. Frozen frontal sections were cut at $20-30 \mu \mathrm{m}$. Typically, five 1 -in-5 series through the hypothalamus were collected in cold cryoprotectant $(0.05$ M sodium phosphate buffer, $30 \%$ ethylene glycol, $20 \%$ glycerol), and stored at $-20^{\circ} \mathrm{C}$ until histochemical analysis. Series of sections destined for in situ hybridization histochemistry were further postfixed in phosphate-buffered $4 \%$ paraformaldehyde overnight at $4^{\circ} \mathrm{C}$ before being transferred to cryoprotectant for storage.

Immunohistochemistry. Series of sections from all experimental animals were stained for Fos protein using a rabbit-derived polyclonal antiserum raised against a synthetic $\mathrm{N}$-terminal fragment of Fos protein (Oncogene Sciences), which was localized using a conventional nickelenhanced avidin-biotin-immunoperoxidase method described elsewhere (Sawchenko et al., 1990). To identify specific cell types displaying NGFI-B mRNA, and to compare the loci of c-fos and NGFI-B expression under challenged conditions, hybridization histochemical localization of NGFI-B was combined with immunoperoxidase staining for tyrosine hydroxylase (TH) in the brainstem, and for Fos, CRF, OT, or AVP in the hypothalamus. For these experiments, immunostaining was 
carried out first, and the two constituent methods were modified to allow efficient dual localization as described elsewhere (Watts and Swanson, 1989). Rabbit antisera against synthetic OT or AVP conjugates were obtained commercially (Chemicon), and were preadsorbed against $100 \mu \mathrm{g} / \mathrm{ml}$ of the heterologous nonapeptide. Rabbit antisera against synthetic CRF-human $\alpha$-globulin conjugates were provided by Dr. W. Vale (The Salk Institute), and details of its characterization and specificity may be found elsewhere (Sawchenko, 1987). Specific staining with each of the antisera employed in the present experiments was blocked following preabsorption overnight at $4^{\circ} \mathrm{C}$ with $30-100 \mu \mathrm{M}$ concentrations of their respective synthetic immunogens.

In situ histochemical hybridization. Hybridization histochemical localization was carried out using ${ }^{35} \mathrm{~S}$-labeled $\mathrm{CRNA}$ probes. Protocols for riboprobe synthesis, hybridization, and autoradiography were adapted after Simmons et al. (1989). All solutions were diethylpyrocarbonate treated to prevent RNA degradation. Tissue sections mounted onto poly-L-lysine-coated slides were desiccated under vacuum overnight, fixed ( $4 \%$ paraformaldehyde, $30 \mathrm{~min})$, digested by proteinase $\mathrm{K}(10 \mu \mathrm{g} /$ $\mathrm{ml}$ in $50 \mathrm{~mm}$ Tris $\mathrm{HCl}, \mathrm{pH} 7.5$, and $5 \mathrm{~mm}$ EDTA, at $37^{\circ} \mathrm{C}$ for $30 \mathrm{~min}$ ), acetylated $(0.25 \%$ acetic anhydride in $0.1 \mathrm{~m}$ triethanolamine, $\mathrm{pH} 8.0)$, and dehydrated. After vacuum drying, $100 \mu \mathrm{l}$ of hybridization mixture $\left(10^{7} \mathrm{cpm} / \mathrm{ml}\right)$ was pipetted on each slide, sealed under a coverslip, and incubated at $55^{\circ} \mathrm{C}$ overnight. The coverslips were then removed, and the slides were rinsed in $4 \times \mathrm{SSC}(1 \times \mathrm{SSC}: 0.15 \mathrm{M} \mathrm{NaCl}, 15 \mathrm{~mm}$ trisodium citrate buffer, $\mathrm{pH} 7.0$ ) at room temperature. They were digested by Ribonuclease A $\left(20 \mu \mathrm{g} / \mathrm{ml}, 37^{\circ} \mathrm{C}, 30 \mathrm{~min}\right)$, and washed in $0.1 \times \mathrm{SSC}$ for $30 \mathrm{~min}$ at $65-85^{\circ} \mathrm{C}$. Sections were exposed at $4^{\circ} \mathrm{C}$ to $\mathrm{x}$-ray film for $72 \mathrm{hr}$, defatted in xylenes, and dipped in NBT2 nuclear emulsion (Kodak; diluted 1:1 with distilled water). Slides were exposed for 5-25 d and developed in D19 developer (Kodak) for 3-5 min at $15^{\circ} \mathrm{C}$. Sections without prior immunoperoxidase staining were counterstained with thionin.

cRNA probes. Antisense and sense (control) cRNA probes for NGFI-B were generated from a 2.4 kilobase (kb) EcoRI fragment of a full-length rat NGFI-B cDNA (Dr. J. Milbrandt, Washington University; Milbrandt, 1988) cloned into pBluescript SK + transcription vector (Stratagene). The identity of the NGFI-B cDNA clone was evaluated by partial DNA sequence analysis (Sanger et al., 1977) using a commercial kit (Sequenase, U.S. Biochemicals). Labeled antisense and sense probes for NGFI-B mRNA were synthesized following linearization with BamH1 or HindIII using T3 or T7 RNA polymerases, respectively (Simmons et al., 1989). The probes for c-fos and prepro-CRF mRNAs were generated from a $2.0 \mathrm{~kb}$ EcoRI insert of a full-length rat c-fos cDNA [Dr. T. Curran, The Roche Institute (Curran and Morgan, 1985)] and a 1.2 $\mathrm{kb}$ EcoRI insert of a full-length rat CRF cDNA [Dr. K. Mayo, Northwestern University (e.g., Imaki et al., 1991)], respectively, cloned into pBluescript SK + vector. The c-fos and prepro-CRF plasmids were linearized with SmaI and HindIII, respectively. Labeled antisense probes for $c$-fos and prepro-CRF $m$ RNA were synthesized using T7 polymerase and SP6 RNA polymerase, respectively. Probes were labeled with $\alpha-{ }^{32} \mathrm{P}$ UTP (New England Nuclear) for Northern blot analysis or $\alpha^{-{ }^{35}} S$-UTP (New England Nuclear) for in situ hybridization. Unincorporated nucleotides were removed by Quick Spin columns (Boehringer Mannheim). The specific activities of the ${ }^{32} \mathrm{P}-\mathrm{UTP}$ and the ${ }^{35} \mathrm{~S}$-UTP probes were on the order of $1-3 \times 10^{9} \mathrm{dpm} / \mu \mathrm{g}$. All restriction enzymes and RNA polymerases were obtained from Promega.

Quantitative analyses. Semiquantitative analyses of hybridization signals for NGFI-B mRNA were carried out in select instances in nuclear emulsion-dipped slides over the confines of cells displaying TH-immunoreactive (-ir) cell bodies in brainstem, or Fos-ir nuclei in PVH and brainstem, using a Leitz optical system coupled to a Macintosh II computer and IMAGE software (version 1.42, W. Rasband, NIH). Optical density of hybridization signal was measured under dark-field illumination at a magnification of $400 \times$ within a circular frame, $10 \mu \mathrm{m}$ (in the medial parvocellular region of $\mathrm{PVH}$ ) or $20 \mu \mathrm{m}$ (in brainstem catecholaminergic cell groups) in diameter, positioned over cells using Fosir nuclei or the nuclei of TH-ir cell bodies as centers of reference. The size of the frame was chosen on the basis of the mean size range of neurons in these respective regions (Milner et al., 1989; Kiss et al., 1991). The optical densitics of grains over cells displaying immunoreactive markers were then corrected for the average background signal, which was determined by sampling cells immediately outside the cell group of interest. Optical densities of five times background were arbitrarily taken as representing positive NGFI-B hybridization signals (McCabe and Pfaff, 1989).

Northern blot analysis. The specificity of the NGFI-B probe was eval- uated by Northern blot analysis. Total RNA was prepared from rat brain and liver by the guanidine-thiocyanate/lithium chloride method (Cathala et al., 1983). Total RNA (15 $\mu \mathrm{g}$ each from whole brain and liver of unperturbed animals) was denatured in $2.2 \mathrm{M}$ formaldehyde and fractionated electrophoretically on a $1.0 \%$ agarose formaldehyde gel in $40 \mathrm{~mm} 3-[N$-morpholino]propanesulfonic acid (MOPS; $\mathrm{pH} 7.0$ ), $10 \mathrm{~mm}$ sodium acetate, and $5 \mathrm{~mm}$ EDTA. After electrophoresis, RNA was transferred to a Hybond-C extra filter (Amersham) and baked under vacuum at $80^{\circ} \mathrm{C}$ for $2 \mathrm{hr}$. The RNA blot was incubated in prehybridization buffer, containing 50\% formamide, $5 \times$ SSPE $(1 \times$ SSPE: $0.01 \mathrm{~m}$ phosphate buffer, $\mathrm{pH} 7.0$, and $0.15 \mathrm{M} \mathrm{NaCl}$ ), $10 \times$ Denhardt's solution (0.02\% BSA, Ficoll 400 , and polyvinylpyrrolidone), $0.5 \%$ sodium dodecyl sulfate (SDS), and $500 \mu \mathrm{g} / \mathrm{ml}$ denatured tRNA, at $60^{\circ} \mathrm{C}$ for $2 \mathrm{hr}$. Hybridization was carried out overnight at $55^{\circ} \mathrm{C}$ in the same buffer with ${ }^{32}$ P-UTP-antisense cRNA probe $\left(2 \times 10^{6} \mathrm{cpm} / \mathrm{ml}\right)$. Washes were performed in $1 \times \mathrm{SSPE}-0.1 \%$ SDS and $0.1 \times \mathrm{SSPE}-0.1 \% \mathrm{SDS}$ at $70^{\circ} \mathrm{C}$. Filters were then exposed to Hyperfilm-MP films (Amersham) with intensifying screens for $9-14 \mathrm{~d}$ at $-70^{\circ} \mathrm{C}$.

\section{Results}

Constitutive NGFI-B $m R N A$ expression in controls. Controls for each of the experimental groups showed patterns of NGFI-B mRNA expression that were similar to those detected in the brains of unperturbed animals. This included constitutively high levels of expression in many telencephalic areas, including the neocortex, basal ganglia, and particularly the hippocampal formation, and low or undetectable levels throughout most of the hypothalamus (Fig. 1). Aspects of the thalamus, particularly the anterior nuclei, also displayed a moderate hybridization signal in control animals. Of prime significance, positively hybridized neurons were either not detected or were rarely encountered in the PVH and supraoptic (SO) nuclei; the only deviation from this occurred in surgical controls for the short (3-6 hr) postADX time point, which displayed a weak signal over both the magnocellular and parvocellular divisions of the $\mathrm{PVH}$, as well as the $\mathrm{SO}$, that we presume to be attributable to surgical trauma and/or stress. Apart from this, the only hypothalamic cell group displaying a consistent and focal NGFI-B mRNA signal in controls was the suprachiasmatic nucleus, though scattered cells were regularly encountered in preoptic, anterior, and lateral hypothalamic areas. While basal levels of $c$-fos expression were generally low throughout the CNS, and in the PVH and SO, in particular, each of the other hypothalamic areas mentioned above contained a greater number of neurons expressing Fos-ir or mRNA than NGFI-B transcripts in both control and nonmanipulated animals.

No detectable basal NGFI-B mRNA expression was evident in major forebrain or medullary cell groups that are known to provide afferents to the $\mathrm{PVH}$, including the nucleus of the solitary tract (NTS), the $\mathrm{Cl}$ and Al catecholamine cell groups of the ventrolateral medulla, and circumventricular organs associated with the lamina terminalis. Each of these basic patterns of results was detected consistently across exposure times ranging between $12 \mathrm{hr}$ and $4 \mathrm{~d}$ for $\mathrm{x}$-ray film, and between 7 and 60 $\mathrm{d}$ for emulsion-dipped slides.

Stimulation-induced patterns of NGFI-B and $c$-fos $m R N A$ in hypothalamic neurosecretory neurons. To evaluate the utility of NGFI-B as an indicator of functional activation in hypothalamic neurosecretory neurons, hybridization histochemical localization of NGFI-B mRNA was carried out in animals subjected to well-established challenge paradigms, including short-term ADX, acute hypotensive hemorrhage, intravenous infusion of IL- $1 \beta$, and chronic salt loading. Since each of these stimuli is known to affect the secretory and/or transcriptional activity of parvocellular neurosecretory CRF-expressing neurons, and to 


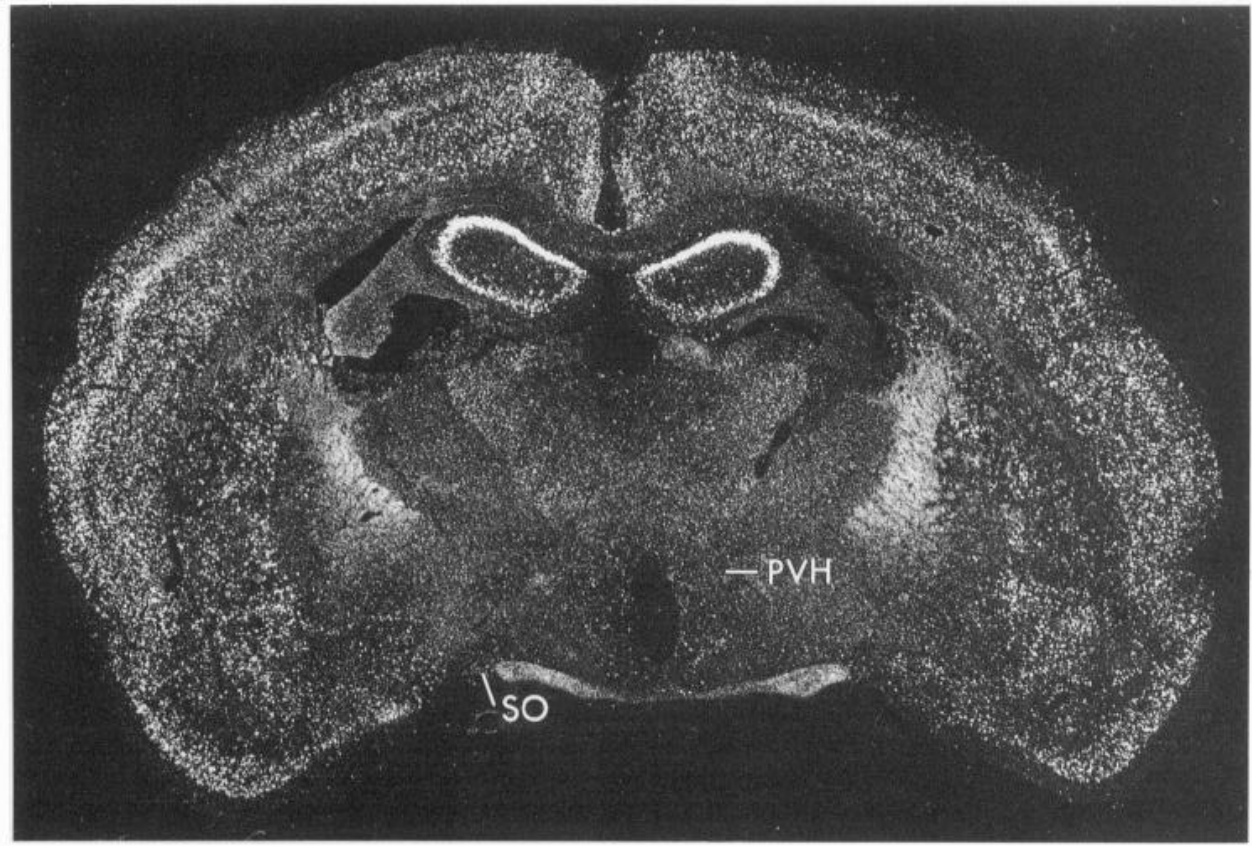

Figure 1. Constitutive NGFI-B mRNA expression in control animals: dark-field photomicrograph of NGFI-B mRNA signal in a control animal. Moderate to high levels of expression are seen in the neocortex, hippocampal formation, basal ganglia, and some subcortical limbic system-associated structures. Most of the hypothalamus, and the $\mathrm{PVH}$ and $\mathrm{SO}$, in particular, are virtually devoid of positively hybridized neurons. This animal was cannulated and received an intravenous injection of vehicle used for IL- $1 \beta$ injection; similar patterns were observed in controls for all treatment paradigms, as well as in unperturbed rats. $P V H$, paraventricular nucleus of the hypothalamus; $S O$, supraoptic nucleus. Magnification, $9 \times$.

result in Fos induction in one or more neuroendocrine cell types, the pattern of NGFI-B expression was compared with the distribution of CRF mRNA, as well as c-fos mRNA and nuclear Fos-ir. Combined immuno- and hybridization histochemical labeling approaches were used to determine the capability of parvocellular neurosecretory CRF and magnocellular neurosecretory OT and AVP neurons to express NGFI-B mRNA. Descriptions of the patterns of expression within the PVH are made with reference to the cytoarchitectonic parcellation scheme of Swanson and Kuypers (1980).

With the exception of salt loading, each of the challenges resulted in an induction of NGFI-B mRNA in the dorsal medial part of the parvocellular division of the $\mathrm{PVH}$, the region in which hypophysiotropic CRF neurons are concentrated, and which is the predominant site of CRF mRNA expression under resting conditions (Fig. 2). Combined hybridization histochemical localization of NGFI-B mRNA and immunohistochemical localization of CRF in animals subjected to ADX, IL- $1 \beta$ infusion, or hemorrhage at time points at which NGFI-B expression is maximal, revealed NGFI-B mRNA to be localized prominently in CRF-ir neurons in the parvocellular PVH (Fig. 3). In contrast to the common, and massive, induction of NGFI-B mRNA in parvocellular region of PVH, the robustness and spatial distribution of NGFI-B mRNA in the two biochemically differentiated compartments of magnocellular division of the $\mathrm{PVH}$, and in the SO, varied markedly as a function of the nature of stimulus (Fig. 2). At the levels chosen for illustration in Figures 2 and 4 , the magnocellular division of the PVH consists principally of a compact ball of AVP-expressing neurons encircled by a ring of OT cells.

$\mathrm{ADX}$ resulted in the most purely parvocellular distribution of NGFI-B mRNA in the PVH, though scattered neurons displaying a clear hybridization signal were detected in both the magnocellular division of the PVH and in the SO. Systemic IL$1 \beta$ infusion also yielded a predominantly parvocellular distribution of NGFI-B mRNA, but with a more substantial level of expression in the magnocellular system, which was concentrated in OT-rich regions (Fig. 2). Hemorrhage, by contrast, induced robust NGFI-B mRNA expression that appeared uniformly distributed across all three neuroendocrine cell types (Fig. 2). Chronic salt loading alone among these challenges resulted in a qualitatively altered pattern of CRF expression in $\mathrm{PVH}$, in which expression in the parvocellular and magnocellular systems was markedly down- and upregulated, respectively (Fig. 2). In keeping with previous reports on the capability of magnocellular neurosecretory neurons to manifest CRF expression (Sawchenko et al., 1984), this was seemingly limited to OT neurons. Associated with this pattern, NGFI-B mRNA was localized almost exclusively in the magnocellular division of the $\mathrm{PVH}$, as well as the SO, and appeared uniformly distributed across their OT and AVP compartments (Fig. 2). Accordingly, widespread colocalization of NGFI-B transcripts within both OTand AVP-ir neurons was readily demonstrated in hemorrhaged (Fig. 3) and salt-loaded rats (Fig. 3).

In each of these challenge paradigms, the distribution of Fosir nuclei followed closely that of NGFI-B mRNA (Figs. 2, 4), particularly in neurosecretory compartments of the $\mathrm{PVH}$ and SO. Combined hybridization histochemical localization of NGFI-B mRNA and immunohistochemical localization of Fosir revealed extensive colocalization of cytoplasmic NGFI-B mRNA signal with nuclear Fos-ir in both subdivisions of PVH (Fig. 4). Quantitative assessments carried out in hemorrhaged rats indicated that $92-98 \%$ of all Fos-ir neurons also displayed a positive hybridization signal for NGFI-B mRNA. Despite the essential similarity in the challenge-induced patterns of expression of the two cIEs, it is worthy of emphasis that discrete, cytoarchitectonically defined, subdivisions of the PVH that contain predominantly non-neuroendocrine neurons displayed a consistently greater capacity for Fos than NGFI-B expression in response to the two acute challenge paradigms (see below).

Time course of NGFI-B and $c$-fos $m R N A$ induction. Since the time courses with which different hypothalamic cell types may be recruited to show modifications in cIE or target gene expression need not necessarily be similar, we followed the in- 

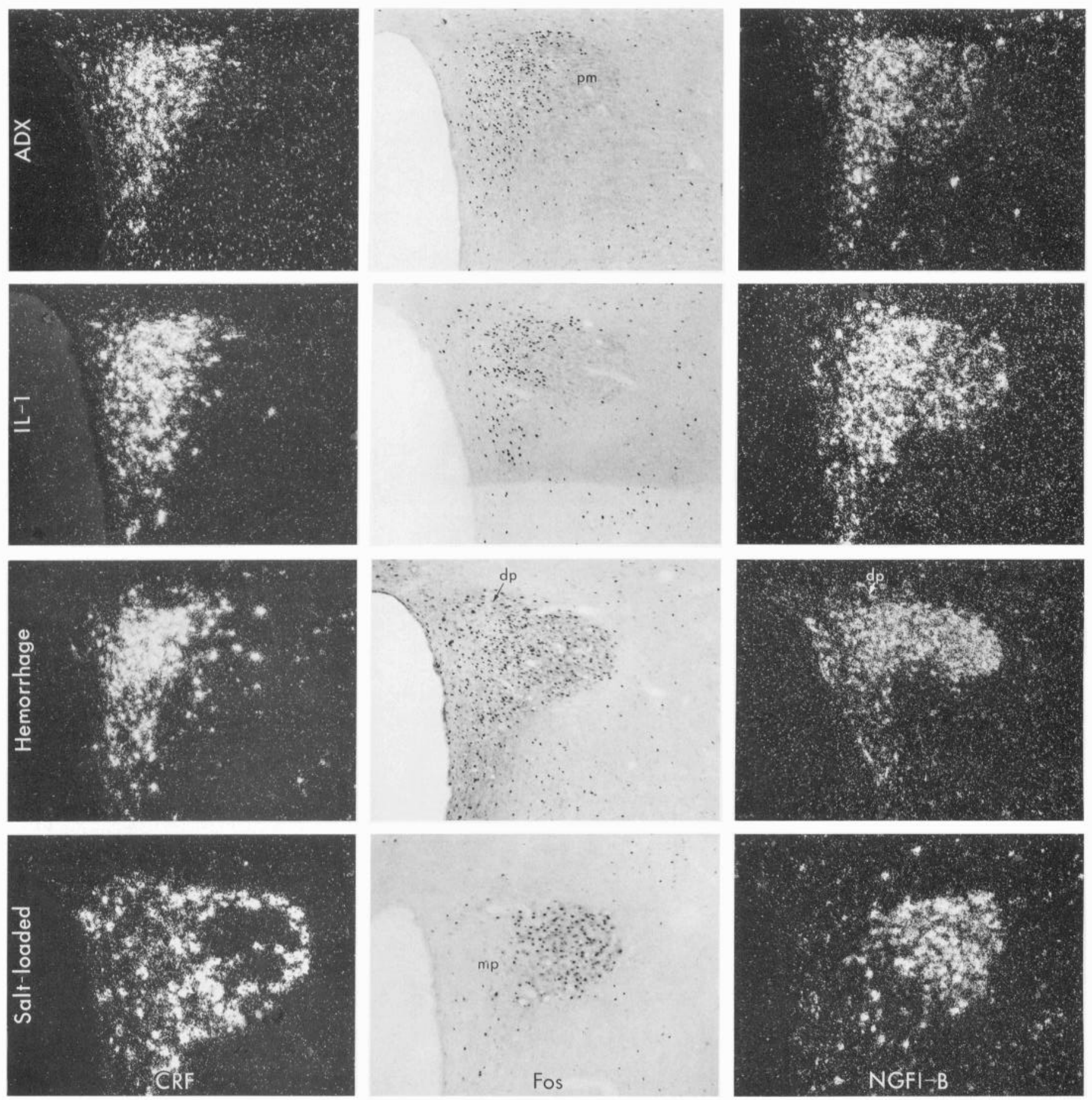

Figure 2. Challenge-specific patterns of CRF mRNA, Fos, and NGFI-B mRNA expression in the PVH: micrographs through a common level of the PVH to compare the patterns of CRF and cIE expression in response to acute ADX, IL-1 $\beta$ injection, hemorrhage, and chronic salt loading. ADX induces patterns of cIE expression that are largely restricted to the dorsal aspect of the medial parvocellular $(m p)$ portion of the PVH, in which hypophysiotropic CRF-expressing cells are concentrated. Fos and NGFI-B responses to IL-1 $\beta$ are similar, but include some involvement of cells in autonomic-related $(\mathrm{dp}$, ventral $\mathrm{mp})$ and magnocellular $(\mathrm{pm})$ portions of the nucleus. Hemorrhage yields a widespread immediate-early gene response in each functional compartment of the PVH. Salt loading, which prompts dramatic down- and upregulation of CRF mRNA in the parvocellular and magnocellular divisions of the $\mathrm{PVH}$, respectively, yields a nearly pure magnocellular locus of cIE induction. Note that, in general, the patterns of Fos and NGFI-B expression are similar, except for a greater capacity for Fos induction exhibited by autonomic-related projection neurons of the PVH. $d p$, dorsal parvocellular subdivision. Magnification, $75 \times$.

duction and disappearance of c-fos and NGFI-B mRNAs in neuroendocrine neurons in the acute stress models. Results obtained following hemorrhage or IL-1 $\beta$ injection were similar, and Figure 5 displays data from hemorrhaged rats. In controls
$(0 \mathrm{hr})$, neither NGFI-B nor c-fos mRNA was detectable in the $\mathrm{PVH}$ or the SO. Within $30 \mathrm{~min}$ after initiation of blood withdrawal, extensive induction of both transcripts appeared within the magnocellular nuclei and in the parvocellular division of 

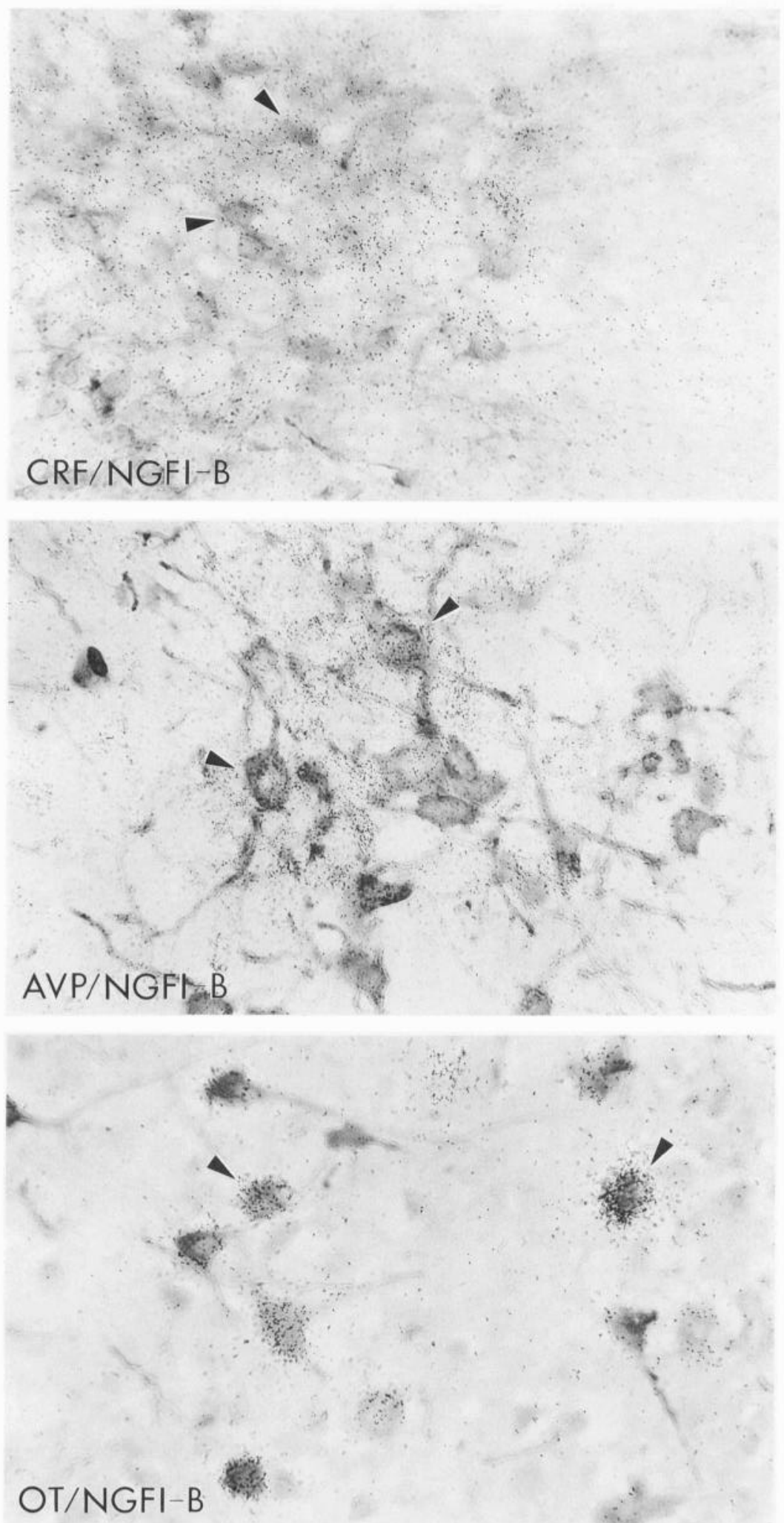

Figure 3. Challenge-induced NGFI-B expression in immunohistochemically identified neuroendocrine neurons: bright-field photomicrographs of combined immunohistochemical (for neuropeptides) and hybridization histochemical (NGFI-B mRNA) preparations. Top, NGFI-B signal over CRFir neurons (arrowheads) in the PVH of a rat killed $6 \mathrm{hr}$ after ADX. Note that the weak CRF-ir signal is characteristic of animals killed at such early post-ADX time points. Middle, NGFI-B signal over AVP-ir neurons $1 \mathrm{hr}$ after hemorrhage. In keeping with the widespread induction of NGFI-B in response to this challenge, hybridization signal is not limited to AVP-ir neurons. Bottom, NGFI-B mRNA signal over OT-ir neurons in the anterior magnocellular part of the PVH, a nearly pure OT cell group, after salt loading. Magnification, 450x. the PVH. The responses of both neuroendocrine cell types peaked at $1 \mathrm{hr}$ after the stimulus, were markedly reduced by $2 \mathrm{hr}$, and were indistinguishable from control levels by $3 \mathrm{hr}$. While the time courses of cIE expression in neurosecretory neurons were similar, differences in other cell types were noted. In particular, the (autonomic nervous system-related) dorsal and ventral-me- dial parts of the parvocellular division of the $\mathrm{PVH}$ reliably showed a greater capacity for c-fos than NGFI-B mRNA expression (Fig. 5).

The time course of IL- $1 \beta$-induced alterations in c-fos and NGFI-B mRNA was quite similar to that seen following hemorrhage; the expression patterns of the two cIEs were similar to 


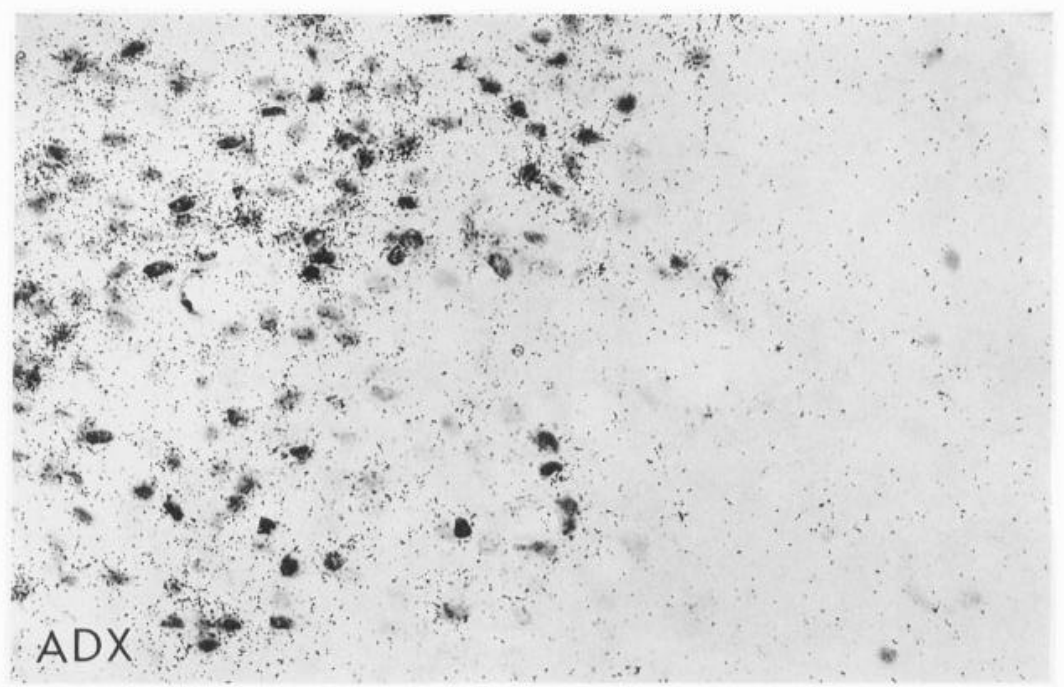

Figure 4. Similarity of challenge-induced patterns of NGFI-B and Fos expression in neuroendocrine neurons of the PVH: bright-field photomicrographs of combined immunohistochemical (Fos-ir) and hybridization histochemical (NGFI-B mRNA) preparations at a level of the PVH similar to that illustrated in Figure 2, in which the dorsal-medial parvocellular subdivision occupies the left half of the field, and the posterior magnocellular subdivision the right half. The patterns of nuclear Fos-ir and cytoplasmic NGFI-B mRNA expression are largely overlapping and largely confined to the parvocellular division (ADX), the magnocellular division (salt loading), or both (hemorrhage). Magnification, $300 \times$.

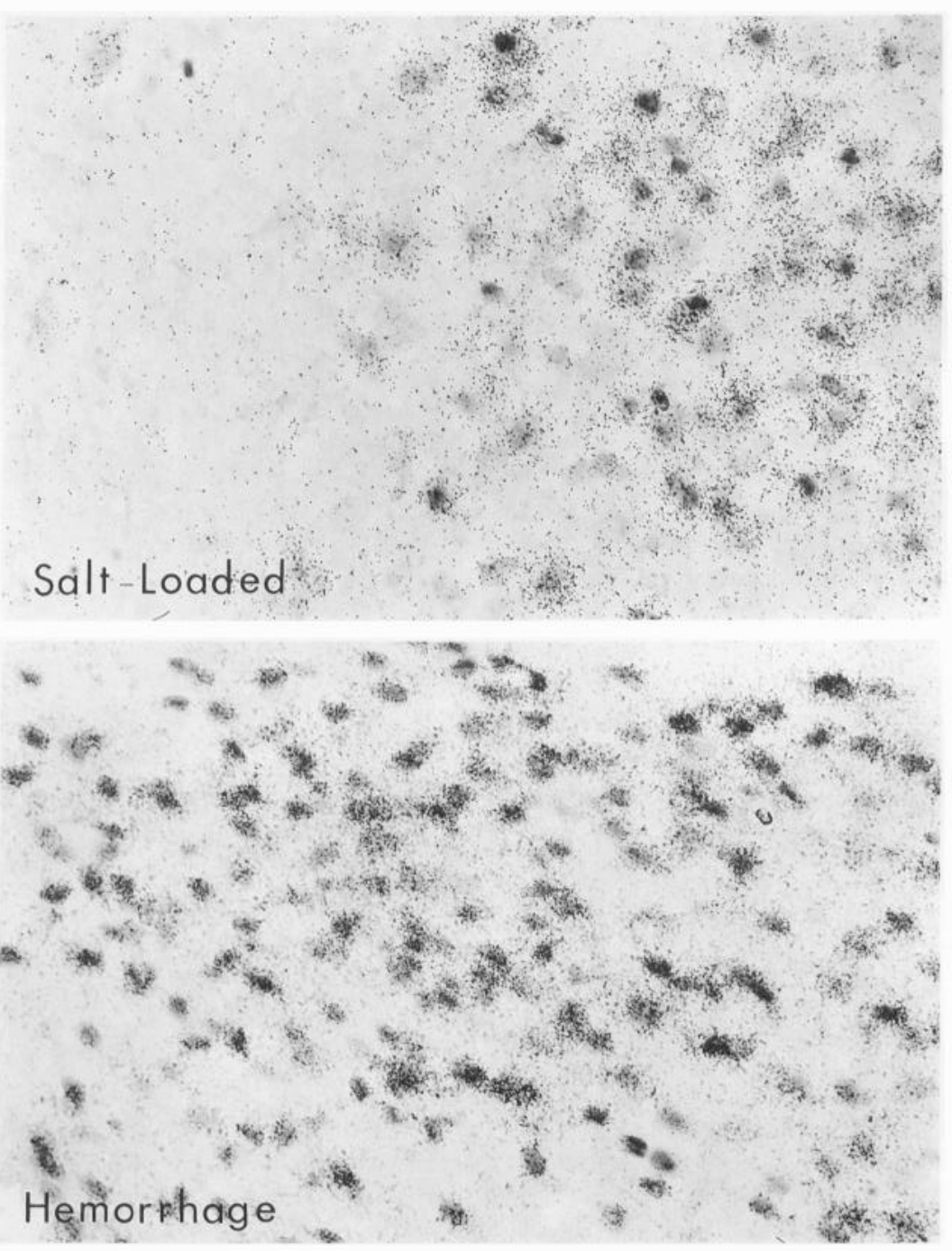

one another, and differed from that induced by hemorrhage in their preferential localization to the parvocellular division of the PVH (Fig. 2). Like hemorrhage, the IL-1 $\beta$ challenge provoked a reliable and long-lasting c-fos mRNA response in the autonomic-related parts of the parvocellular PVH that was mut- ed or lacking in sections from the same animals hybridized for NGFI-B mRNA.

Expression of NGFI-B mRNA in hypothalamic afferents. Possible expression of NGFI-B mRNA in cell groups implicated in the transduction and/or conveyance of stress-related informa- 

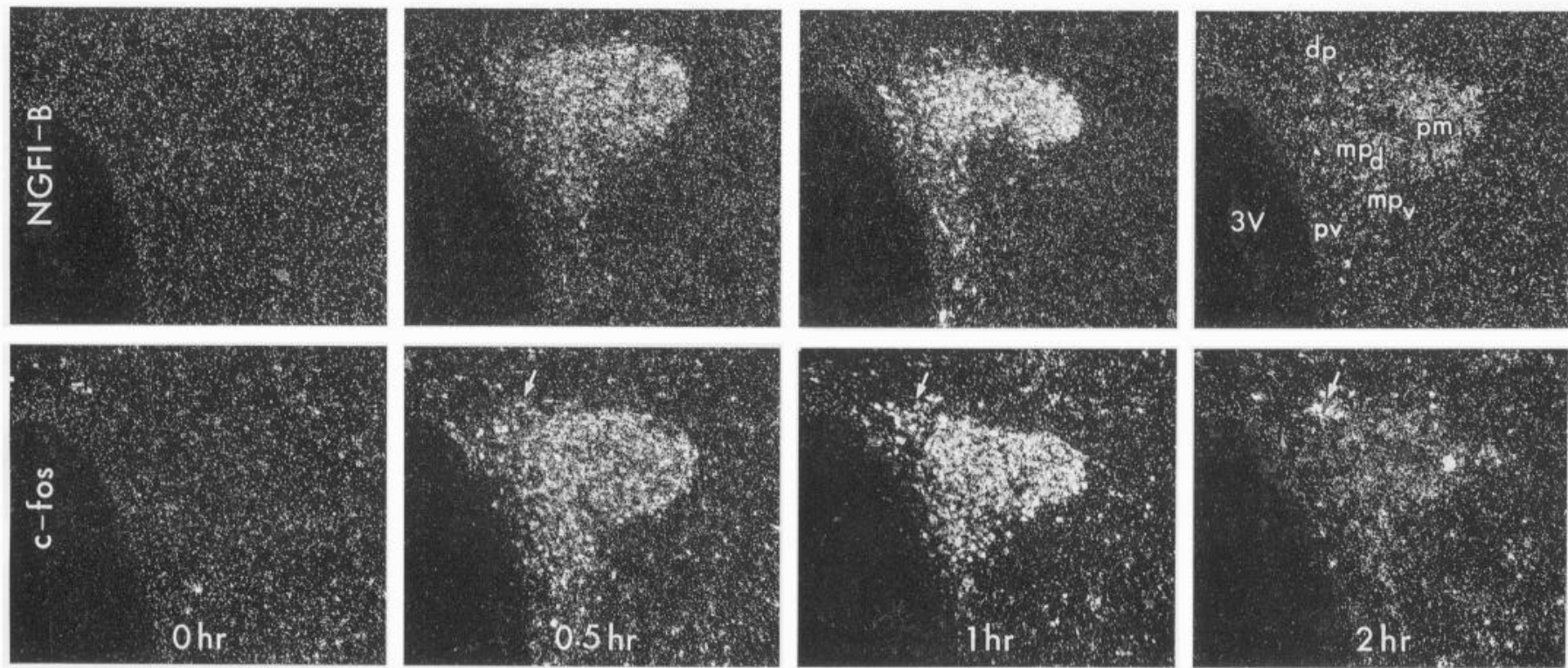

Figure 5. Stimulus-induced NGFI-B and c-fos mRNA expression in the PVH follow similar time courses: da.k-field photomicrographs of sections through a comparable level of the PVH from animals killed at varying intervals after $15 \%$ hemorrhage, and in controls $(0 \mathrm{hr})$. Significant and widespread induction of both transcripts is evident at $0.5 \mathrm{hr}$, peaks at about $1 \mathrm{hr}$, is diminished by $2 \mathrm{hr}$, and is not detectable by $3 \mathrm{hr}$ (not shown) after the challenge. Note that the subnuclear patterns of expression of the two markers are similar, except for the autonomic-related dorsal (arrows) and ventral medial parvocellular subdivisions of the PVH, which again show a greater capacity for c-fos than NGFI-B induction. Similar time courses for the two markers were also noted following IL- $1 \beta$ injection. $3 V$, third ventricle; $d p$, dorsal parvocellular subdivision; $m p_{d}$, dorsal medial parvocellular subdivision; $m p_{v}$, ventral medial parvocellular subdivision; $p m$, magnocellular subdivision; $p v$, periventricular subdivision of $\mathrm{PVH}$. Magnification, $45 \times$.

tion to the PVH and SO was examined in the acute (hemorrhage and IL- $1 \beta$ infusion) and chronic (salt loading) stress models. These include the medullary $\mathrm{C} 1$ and $\mathrm{C} 2$ adrenergic cell groups and the noradrenergic $\mathrm{A} 1$ and $\mathrm{A} 2$ cell groups for the acute challenges, and a series of interconnected cell groups comprising the lamina terminalis (subfornical organ, median preoptic nucleus, organum vasculosum) for chronic hyperosmotic stimulation. Induction of c-fos mRNA and/or Fos protein has been reported in these regions in response to the respective stimuli (Giovannelli and Bloom, 1992; Hamamura et al., 1992; Ericsson and Sawchenko, 1993; Kovács and Sawchenko, 1993), and these observations were confirmed here (it might also be noted that a functionally related circumventricular structure, the area postrema, showed a clear hybridization signal in hemorrhaged rats). It is important to point out that c-fos induction in each of these regions was readily detected at time points, and autoradiographic exposure times, that were similar to those required for detection of c-fos or NGFI-B mRNA in the hypothalamus.

By contrast, NGFI-B mRNA was generally not detectable (Fig. 6) in these afferent sources in the same brains using the same autoradiographic exposure times (typically 9-14 d) that revealed robust NGFI-B hybridization signal in neuroendocrine neurons of the PVH and SO (e.g., Figs. 2-5). Only when longer exposure times were employed (21-25 d) was challenge-specific induction of NGFI-B mRNA detectable in these regions. Under these conditions, the distribution of extrahypothalamic cells displaying a positive hybridization signal for NGFI-B conformed closely to those manifesting c-fos mRNA or Fos protein expression. In the case of the acute challenges, this was evaluated by assessing the extent to which NGFI-B mRNA was colocalized in medullary neurons also displaying TH- or Fos-ir (Fig. 6). Quantitative analyses in seven rats killed at $1 \mathrm{hr}$ following hemorrhage indicated that $75-84 \%$ of all cells in the dorsomedial or ventrolateral medulla that contained Fos-ir nuclei were also positively hybridized for NGFI-B mRNA (Fig. 6). With regard to colocalization with the catecholamine biosynthetic enzyme, $31 \%$ and $42 \%$ of cells displaying a positive hybridization signal for NGFI-B mRNA in the caudal and rostral parts of the nucleus of the solitary tract, respectively, also displayed TH-ir. More extensive colocalization was observed in the regions of the ventrolateral medullary Al (82\%) and Cl cell groups (88\%; Fig. 6). Similar differences in the relative detectability of $\mathrm{c}-f o s$ and NGFI-B mRNA expression were evident in lamina terminalisassociated structures in salt-loaded animals and in medullary catecholamine neurons following an IL- $1 \beta$ challenge (data not shown).

Specificity of NGFI-B cRNA probe. Partial DNA sequence and Northern blot analyses were carried out to confirm the identity and specificity of the NGFI-B cRNA probe (data not shown). The former revealed a perfect correspondence with the published sequence over an approximately 250 base pair long region of the clone, which included principally the $5^{\prime}$ untranslated region of the cDNA (Milbrandt, 1988). Similarly, Northern blot analysis of total RNA preparations from whole brain, but not liver, revealed a single hybridization band of approximately 2.4 $\mathrm{kb}$, which corresponds to the size of rat NGFI-B mRNA published previously (Milbrandt, 1988).

\section{Discussion}

The present results demonstrate transient induction of NGFI-B mRNA in hypothalamic neurosecretory CRF, AVP, and OT neurons with time courses and in patterns that are consistent with the manner in which these cell types are thought to be affected by the individual challenge models that we employed. The spatial and temporal distribution of NGFI-B mRNA conformed closely to those of nuclear Fos-ir and c-fos mRNA in 

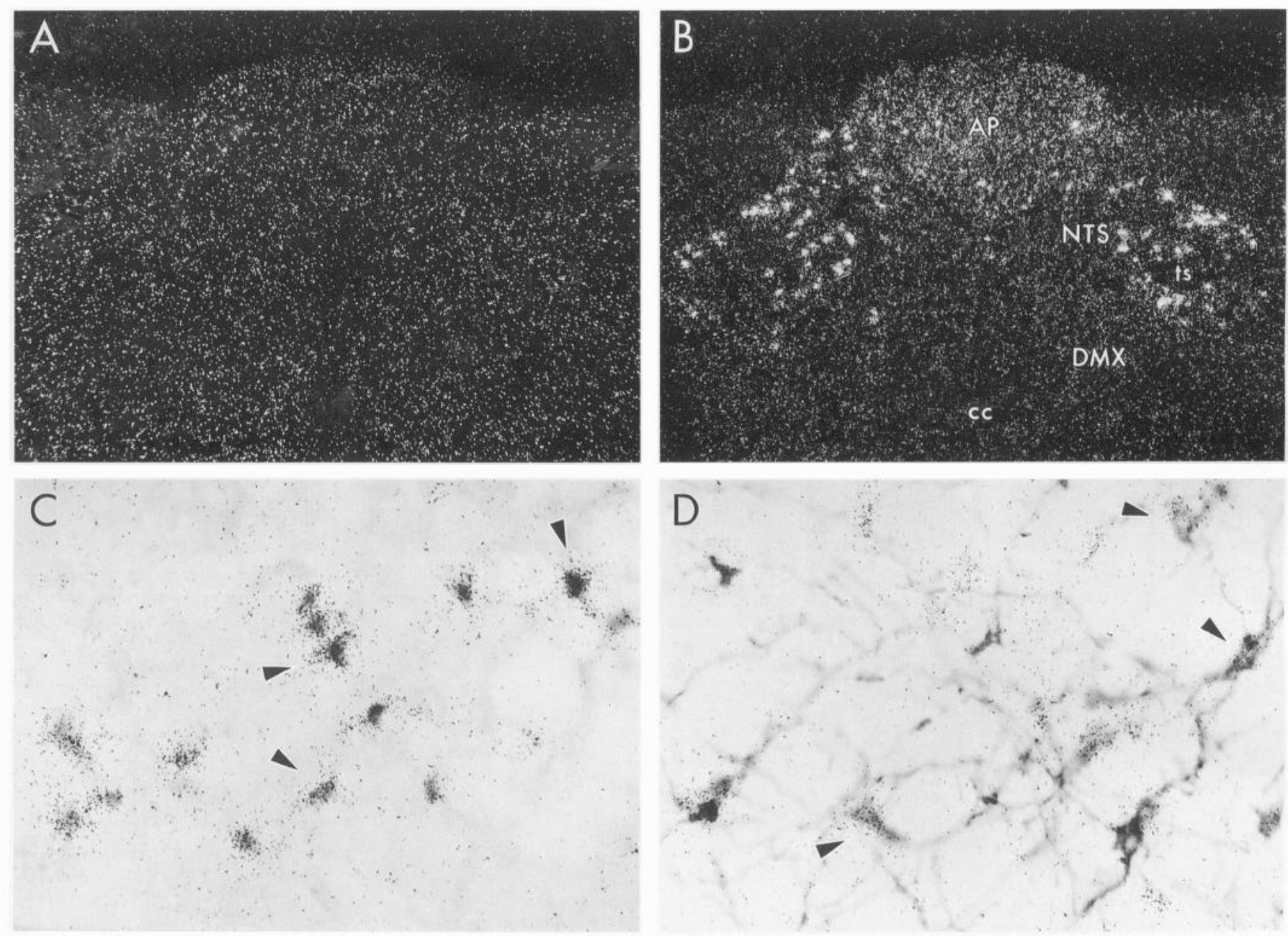

Figure 6. Differential responsiveness of relevant afferents to the PVH in revealing stimulation-induced activation of c-fos and NGFI-B mRNA expression. Previous studies demonstrated hemorrhage-induced Fos expression in medullary catecholamine neurons that project to the PVH. $A$, NGFI-B signal is not detectable in the dorsomedial medulla of a hemorrhaged animal under hybridization conditions that revealed positive signals for c-fos and NGFI-B mRNA in the PVH (exposure time, $11 \mathrm{~d}$ ). B, Sections from the same brain, hybridized with the same batch of probe, but in which longer exposure times ( $>3$ weeks) were used for autoradiograms, reveals challenge-specific NGFI-B expression in both the nucleus of the solitary tract $(N T S)$ and area postrema $(A P)$, as well as in the ventrolateral medulla $(C$ and $D)$, areas known to project to the PVH. Combined immuno- and hybridization histochemical labeling revealed NGFI-B mRNA to colocalize with both hemorrhage-induced Fos-ir $(C)$ and TH-ir $(D)$ in ventrolateral medullary neurons. Afferents implicated as relevant to the effects of IL-1 $\beta$ (medullary catecholamine neurons) and salt loading (lamina terminalis-associated structures) showed similar differences in the detectable levels of c-fos and NGFI-B expression (not shown). Arrowheads mark neurons displaying both markers. $c c$, central canal; $D M X$, dorsal motor nucleus of vagus; $t s$, solitary tract. Magnification: $A$ and $B, 75 \times$; $C$ and $D, 300 \times$.

each of the stimulus paradigms, particularly in neurosecretory compartments of the PVH and SO; the only disparity lay in the more robust expression of c-fos than NGFI-B mRNA in autonomic-related subdivisions of the PVH. Furthermore, while both c-fos and NGFI-B were coexpressed in a stress-specific manner in extrahypothalamic neurons that provide afferents to the $\mathrm{PVH}$, NGFI-B expression was less readily detectable than that of c-fos in some regions, including medullary catecholamine cell groups and a triad of functionally related structures comprising the lamina terminalis of the third ventricle. Overall, the results support the general utility of c-fos as a marker for functional activation at multiple levels of stress-related neuroendocrine circuitry. In addition, they suggest NGFI-B, a cIE more apt to be involved in the regulation of neuroendocrine gene expression, to be a useful alternative or adjunct marker at the level of hypothalamic neurosecretory neurons, at least.

Challenge-dependent expression of cIEs in hypothalamic neu- rosecretory neurons. While resting levels of Fos expression are acknowledged as being low in most brain regions, there is a limited amount of data on constitutive NGFI-B expression in brain. In line with the present results, previous studies described significant basal levels of expression of this gene, particularly in telencephalic regions, as well as stimulation-induced increases in NGFI-B mRNA or protein expression in neocortex, hippocampal formation, and spinal cord (Watson and Milbrandt, 1989; Wisden et al., 1990; Mack and Mack, 1992). The principal aim of the present study was to compare NGFI-B and c-fos expression in hypothalamic neurosecretory neurons in response to well-established challenge paradigms that target them in various combinations.

Feedback inhibition by circulating glucocorticoids is acknowledged as the major negative regulator of CRF expression in parvocellular neurosecretory neurons that constitute the central limb of the HPA axis. Previous studies of surgical or pharma- 
cological ADX have described increased expression and transcription of the CRF gene in parvocellular neurosecretory neurons, as well as increased hypothalamic and portal plasma CRF peptide content (Dallman et al., 1987; Plotsky, 1991). These effects are accompanied by increased expression in the same neurons of additional secretagogues for corticotropin, notably AVP (Sawchenko and Swanson, 1990). Each of these effects is steroid reversible (Dallman et al., 1987; Plotsky, 1991). Circumscribed ADX-induced Fos expression in identified CRF neurons of the PVH has been demonstrated (Jacobson et al., 1990). Similarly, we found ADX to result in prompt, and comparably focal, induction of NGFI-B and c-fos expression in CRFir cells of the PVH.

IL- $1 \beta$ infusion and hypotensive hemorrhage provided models of acute activation of hypothalamic neurosecretory compartments by stimuli of distinctive modalities. Many previous studies have shown that central or peripheral administration of IL1 yields dose-dependent increases in biosynthesis and secretion of CRF (e.g., Berkenbosch et al., 1987; Sapolsky et al., 1987; Suda et al., 1990); this model has attracted interest as reflecting a postulated feedback control of neuroendocrine events by the immune system. While the routes by which IL-1 comes to alter HPA axis output remain unsettled, the weight of evidence supports an ultimate site of action at the hypothalamus. Previous studies have demonstrated that IL- $1 \beta$ administered centrally (Ju et al., 1991; Rivest et al., 1992) or peripherally (Ericsson and Sawchenko, 1993) gives rise to a predominantly parvocellular distribution of Fos-ir in the PVH, which can be localized to CRF-expressing neurons. The present results with both cIEs support this pattern, and reveal a secondary accumulation in OT-rich regions of the magnocellular system. The literature is conflicting as to whether IL- $1 \beta$ may provoke the release of AVP and/or OT from magnocellular neurons (Sapolsky et al., 1987; Berkenbosch et al., 1989; Naito et al., 1991; Takahashi et al., 1992). IL- $1 \beta$-mediated induction of NGFI-B mRNA in medullary catecholamine groups is compatible with recent findings that systemic IL- $1 \beta$ stimulates hypothalamic norepinephrine metabolism, and that depletion of noradrenergic inputs to hypothalamus attenuates the release of corticostcronc induced by systemic IL-1 $\beta$ (Dunn, 1988; Matta et al., 1990). Furthermore, our own data indicate that transection of ascending aminergic pathways eliminates IL- $1 \beta$-stimulated increases in Fos-ir and CRF mRNA levels in the PVH (Ericsson and Sawchenko, 1992, 1993).

A second acute challenge model, experimentally induced hypotensive hemorrhage, has been reported to provoke increased electrical activity of identified magnocellular neurosecretory, parvocellular neurosecretory, and autonomic neurons in the PVH (Day et al., 1984; Kannan and Yamashita, 1985; Kannan et al., 1987), as well as increased systemic AVP and OT (Gibbs, 1986), and increased portal plasma levels of CRF, AVP, and OT (Plotsky and Vale, 1984; Plotsky et al., 1985). The present demonstration of robust NGFI-B and c-fos expression appearing uniformly distributed across all major neuroendocrine and autonomic-related cell types in PVH is in keeping with the widespread involvement of CRF, AVP, and OT neurons in responses associated with metabolic mobilization and pressure and volume compensation following hemorrhage (for review, see Cowley, 1992). Furthermore, the induction of both cIEs in medullary catecholamine cell groups is consistent with previous findings that hemorrhage triggers activation of the catecholamine metabolism in the ventrolateral medulla (Quintin et al.,
1987; Ponec et al., 1992), and that catecholaminergic projections from the medulla play pivotal roles in relaying pressure and volume-related information to the $\mathrm{PVH}$ and $\mathrm{SO}$ to mediate compensatory neuroendocrine responses (see Sawchenko and Swanson, 1982; Plotsky et al., 1989).

Salt loading is clearly distinct from the other challenge models considered here in presenting a chronic stimulus that is known to downregulate CRF expression in the parvocellular neurosecretory system, while coordinately upregulating it in magnocellular neurosecretory OT neurons. Diminished secretory activities of the anterior pituitary and adrenal glands have been reported in this model (Jessop et al., 1989), as have increased expression and secretion of AVP and OT in the magnocellular neurosecretory system. Similar hyperosmotic challenge paradigms have been shown to result in widespread Fos induction in magnocellular neurosecretory neurons and in each of the three major cellular components of the lamina terminalis (Giovannelli and Bloom, 1992; Hamamura et al., 1992). We have recently provided evidence to indicate that disruption of lamina terminalis projections to the endocrine hypothalamus abolishes the effect of salt loading on CRF expression in both the magnocellular and parvocellular systems (Kovács and Sawchenko, 1993). Patterns of c-fos and NGFI-B induction were, once again, concordant in revealing activational effects in magnocellular neurons and their potentially related afferents. It is of interest that, despite the normally transient nature of cIE expression, which in the case of c-fos derives from autoinhibition (Morgan and Curran, 1991), both c-fos and NGFI-B induction were well maintained in magnocellular neurons in response to persisting hypersomolality. It is also worth emphasizing that neither c-fos nor NGFI-B marked the salt loading-induced inhibitory event (i.e., decreased CRF mRNA expression) in parvocellular neurosecretory neurons. The lack of an established indicator, cIE or otherwise, for situationally diminished cellular activity remains an impediment to mapping complex polysynaptic circuits.

$c$-fos and NGFI-B compared. Overall, the results support the view that NGFI-B may serve as a viable marker of functional activation in stress-related parvo- and magnocellular neurosecretory neurons. As summarized above, the induced patterns of immediate-early gene expression are broadly consistent with the existing literature as to which cell types are affected by the individual challenge models we employed. In addition, the patterns and time courses of NGFI-B induction were similar to those of c-fos across a range of treatment paradigms.

Outside of neuroendocrine neurons, however, caveats must be attached to the overall similarities in the stimulus-induced expression patterns of the two markers. While NGFI-B mRNA was detectable in all major $\mathrm{PVH}$ cell types and related afferents, differences in the abilities of components of the system to manifest NGFI-B expression were apparent. These included neurons in autonomic-related parts of the $\mathrm{PVH}$, which more readily displayed c-fos than NGFI-B mRNA in response to acute stresses (Fig. 5). Although we did not formally localize cIE expression in these models to identified autonomic projection neurons, the fact that nearly all cells of the dorsal parvocellular part of the $\mathrm{PVH}$ give rise to long descending projections (Sawchenko and Swanson, 1982) strongly supports this localization. In addition, neurons implicated in relaying stress-related information to the PVH were not readily detected using autoradiographic exposure times that were adequate to reveal either NGFI-B mRNA in hypothalamic neurons or c-fos in medullary afferents. Only after 
extended exposure times were NGFI-B mRNA signals compatible with induced patterns of $\mathrm{c}$-fos expression in the medulla. These findings suggest that reliance on a single cIE as a marker for functional activation could be misleading, and point to the importance of employing multiple markers in attempts to delineate operational circuits.

An NGFI-B response clement (NBRE) has been identified and functionally characterized (Wilson et al., 1991, 1993), and contains a 6-base (5'-AGGTCA-3') motif corresponding to an estrogen/thyroid hormone receptor response element half-site (Wilson et al., 1991). A GenBank search was performed using FASTA software (Pearson and Lipman, 1988) for NBRE-like sequences based on a perfect match with this motif, AGGTCA, plus at least one additional $5^{\prime}$ adenosine (Wilson et al., 1991). The promotor regions of the rat CRF (Thompson et al., 1987; accession no. M54987), AVP (Mohr and Richter, 1990; accession no. Y07531), and OT (Ivell and Richter, 1984; accession no. K01701) genes were found to contain one or more potential NBRE-like sequences. Whether any of the putative NBREs on the CRF, AVP, and OT promoters is capable of NGFI-B binding and transcriptional activation remains to be demonstrated. Their presence does, however, identify potential substrates for direct cIE-ncuroendocrine target gene interaction, which, except for the AVP gene, is lacking for AP-1-related factors. It must be emphasized, however, that the absence of AP-1 sites in both the CRF and OT genes does not necessarily negate a role for Fos in the regulation of these genes. While Fos-Jun dimers commonly participate in transcriptional regulation by AP-1 binding (Chiu et al., 1988; Curran and Franza, 1988; Morgan and Curran, 1991), other mechanisms are possible, and include the demonstrated functional antagonism between Fos or Jun and the glucocorticoid receptor via protein-protein interactions (Schule et al., 1990; Yang-Yen et al., 1990).

Little is known of whether the multiple cIEs that may be expressed in a particular cell type function in series or in parallel, and which, if any, may be strictly required for transcriptional activation. This, coupled with the capacity for phenotypic plasticity of neuroendocrine neurons, makes it clear that direct transcriptional regulation of the CRF, AVP or OT genes cannot be inferred simply from patterns of challenge-induced cIE expression. However, in identifying cell types affected by a given stimulus, patterns of c-fos and NGFI-B expression do provide starting points from which to pursue experimentally the functional associations between cell groups, and stimulus influences on effector molecules of interest.

\section{References}

Antoni FA (1986) Hypothalamic control of adrenocorticotropin secretion: advances since the discovery of 41 -residue corticotropinreleasing factor. Endocr Rev 7:351-378.

Antoni FA, Fink G, Sheward WJ (1990) Corticotropin-releasing peptides in rat hypophyseal portal blood after paraventricular lesions: a marked reduction in the concentration of corticotrophin-releasing factor-41, but no change in vasopressin. J Endocrinol 125:175-183

Badoer EM, McKinley MJ, Oldfield BJ, McAllen RM (1992) Distribution of hypothalamic, medullary and lamina terminalis neurons expressing Fos after hemorrhage in conscious rats. Brain Res 582: 323-328.

Berkenbosch F, Oers JV, Rey AD, Tilders F, Besedovsky H (1987) Corticotropin-releasing factor-producing neurons in the rat activated by interleukin-1. Science 238:524-526.

Berkenbosch F, de Goeij DE, Rey AD, Besedovsky HO (1989) Neuroendocrine, sympathetic and metabolic responses induced by interleukin-1. Neuroendocrinology 50:570-576.

Brown ER, Chan RKW, Kovács K, Sawchenko PE (1992) Preferential induction of the immediate-early gene, NGFI-B, in hypothalamic neurons in response to stressors or corticosteroid withdrawal. Soc Neurosci Abstr 18:666.

Bullitt E (1990) Expression of c-fos-like protein as a marker for neuronal activity following noxious stimulation in the rat. J Comp Neurol 296:517-530.

Cathala G, Savouret J-F, Mendez B, West BL, Karin M, Martial JA, Baxter JD (1983) A method for isolation of intact, translationally active ribonucleic acid. DNA 2:329-335.

Ceccatelli S, Villar MJ, Goldstein M, Hökfelt T (1989) Expression of c- $f \circ s$ immunoreactivity in transmitter-characterized neurons after stress. Proc Natl Acad Sci USA 86:9569-9573.

Chiu R, Boyle WJ, Meek J, Smeal T, Hunter T, Karin M (1988) The c-fos protein interacts with c-Jun/AP-1 to stimulate transcription of AP-1 responsive genes. Cell 54:541-552.

Cowley AW (1992) Long-term control of arterial blood pressure. Physiol Rev 72:231-300.

Curran T, Franza BR Jr (1988) Fos and Jun: the AP-1 connection. Cell 55:395-397.

Curran T, Morgan JI (1985) Superinduction of c-fos by nerve growth factor in the presence of peripherally active benzodiazepines. Science 229:1265-1268.

Dallman MF, Akana SF, Cascico CS, Darlington DN, Jacoboson L, Levin L (1987) Regulation of ACTH secretion: variations on a theme of B. Recent Prog Horm Res 43:113-173.

Day TA, Ferguson AV, Renaud LP (1984) Facilitatory influence of noradrenergic afferents on the excitability of rat paraventricular nucleus neurosecretory cells. J Physiol (Lond) 355:237-249.

Dragunow M, Faull RL (1989) The use of c-fos as a metabolic marker in neuronal pathway. J Neurosci Methods 29:261-265.

Dunn AJ (1988) Systemic interleukin-1 administration stimulates hypothalamic norepinephrine metabolism paralleling the increased plasma corticosterone. Life Sci 43:429-435.

Ericsson A, Sawchenko PE (1993) c-fos-based functional mapping of central pathways subserving the effects of interleukin- 1 on the hypothalamo-pituitary-adrenal axis. In: Methods in neuroscience, Vol. 16, The neurobiology of cytokines (De Souza EB, ed), pp 155-172. New York: Academic.

Fricsson A, Amaral DG, Sawchenko PE (1992) Systemic administration of interleukin- $1 \beta$ results in increased levels of NGFI-B mRNA in the endocrine hypothalamus and its medullary afferents. Soc Neurosci Abstr 18:1013.

Evans RM (1988) The steroid and thyroid hormone receptor superfamily. Science 240:889-895.

Gibbs DM (1986) Vasopressin and oxytocin: hypothalamic modulators of the stress response: a review. Psychoneuroendocrinology 11: $131-140$.

Giovannelli L, Bloom FE (1992) c-fos protein expression in the rat subfornical organ following osmotic stimulation. Brain Res 139:1-6.

Hamamura M, Nunez DJR, Leng G, Emson PC, Kiyama H (1992) c-fos may code for a common transcription factor within the hypothalamic neural circuits involved in osmoregulation. Brain Res 572: 42-51.

Harbuz MS, Lightman SL (1992) Stress and the hypothalami-pituitary-adrenal axis: acute, chronic and immunological activation. $J$ Endocrinol 134:327-339.

Hazel TG, Nathans D, Lau LF (1988) A gene inducible by serum growth factors encodes a member of the steroid and thyroid hormone receptor superfamily. Proc Natl Acad Sci USA 85:8444-8448.

Hazel TG, Misra R, Davis IJ, Greenberg ME, Lau LF (1991) Nur 77 is differentially modified in PC1 2 cells upon membrane depolarization and growth factor treatment. Mol Cell Biol 11:3239-3246.

Herman JP, Schafer MKH, Thompson RC, Watson SJ (1992) Rapid regulation of corticotropin-releasing hormone gene transcription in vivo. Mol Endocrinol 6:1061-1069.

Holmes MC, Antoni FA, Aguilera G, Catt KJ (1986) Magnocellular axons in passage through the median eminence release vasopressin. Nature 319:326-329.

Imaki T, Nahan JL, Rivier C, Sawchenko PE, Vale W (1991) Differcntial rcgulation of corticotropin-releasing factor $m R N \Lambda$ in rat brain regions by glucocorticoids and stress. J Neurosci 11:585-599.

Imaki T, Shibasaki T, Hotta M, Demura H (1992) Early induction of c-fos precedes increased expression of corticotropin-releaing factor messenger ribonucleic acid in the paraventricular nucleus after immobilization stress. Endocrinology 131:240-246. 
Ivell R, Richter D (1984) Structure and comparison of the oxytocin and vasopressin genes from rat. Proc Natl Acad Sci USA 81:20062010.

Jacobson L, Sharp FR, Dallman MF (1990) Induction of Fos-like immunoreactivity in hypothalamic corticotropin-releasing factor neurons after adrenalectomy in the rat. Endocrinology 126:17091719.

Jcssop DS, Eckland DJA, Todd K, Lightman SL (1989) Osmotic regulation of hypothalamus-neurointermediate lobe corticotropin-releasing factor-41 in the rat. J Endocrinol 120:119-124.

Ju G, Zhang X, Jin BQ, Huang CS (1991) Activation of corticotropinreleasing factor-containing neurons in the paraventricular nucleus of the hypothalamus by interleukin-1 in the rat. Neurosci Lett 132:151154.

Kannan H, Yamashita H (1985) Electrophysiological study of paraventricular nucleus projecting to the dorsomedial medulla and their response to baroreceptor stimulation in rats. Brain Res 279:31-40.

Kannan H, Kasai M, Osaka T, Yamashita H (1987) Neurons in the paraventricular nucleus projecting to the median eminence: a study of their afferent connections from peripheral baroreceptors, and from the A1-catecholaminergic area in the ventrolateral medulla. Brain Res 409:358-363.

Keller-Wood ME, Dallman MF (1984) Corticosteroid inhibition of ACTH secretion. Endocr Rev 5:1-24.

Kiss JZ, Martos J, Palkovits M (1991) Hypothalamic paraventricular nucleus: a quantitative analysis of cytoarchitectonic subdivisions in the rat. J Comp Neurol 313:563-573.

Kovács K, Sawchenko PE (1993) Mediation of osmoregulatory influences on neuroendocrine CRF expression by the ventral lamina terminalis. Proc Natl Acad Sci USA 90:7681-7685.

Labiner DJ, Butler LS, Zhen C, Hosford DA, Shin C, McNamara JO (1993) Induction of c-fos mRNA by kindled seizures: complex relationship with neuronal burst firing. J Neurosci 13:744-751.

Mack KJ, Mack PA (1992) Induction of transcription factors in somatosensory cortex after tactile stimulation. Mol Brain Res 12:141147.

Matta SG, Singh J, Newton R, Sharp BM (1990) The adrenocorticotropin response to interleukin- $1 \beta$ instilled into the rat median eminence depends on the local release of catecholamines. Endocrinology 127:2175-2182.

McCabe JT, Pfaff DW (1989) In situ hybridization: a methodological guide. In: Methods in neuroscience, Vol 1, Gene probes (Conn PM, ed), pp 98-126. New York: Academic.

Milbrandt J (1988) Nerve growth factor induces a gene homologous to the glucocorticoid receptor gene. Neuron 1:183-188.

Milner TA, Pickel VM, Morrison SF, Reis DJ (1989) Adrenergic neurons in the rostral ventrolateral medulla: ultrastructure and synaptic relations with other transmitter-identified neurons. In: Progress in brain research, Vol 81 (Ciriello J, Caverson MM, Polosa C, eds), pp 29-47. Amsterdam: Elsevier.

Mohr E, Richter D (1990) Sequence analysis of the promoter region of the rat vasopressin gene. FEBS Lett 260:305-308.

Morgan JI, Curran T (1989) Stimulus-transcription coupling in neurons: role of cellular primary response genes. Trends Neurosci 12: 459-462.

Morgan JI, Curran T (1991) Stimulus-transcription coupling in the nervous system: involvement of the inducible proto-oncogenes fos and jun. Annu Rev Neurosci 14:421-451.

Naito $Y$, Fukata J, Shindo K, Ebisui $O$, Murakami N, Tominaga $T$, Nakai Y, Mori K, Kasting NW, Imura H (1991) Effects of interleukins on plasma arginine vasopressin and oxytocin levels in conscious, freely moving rats. Biochem Biophys Res Commun 174:1189-1195.

Nakai A, Kartha S, Sakurai A, Toback FG, DeGroot LJ (1990) A human early response gene homologous to murine nur77 and rat NGFI-B, and related to the nuclear receptor superfamily. Mol Endocrinol 4:1438-1443.

Pearson WR, Lipman DJ (1988) Improved tools for biological sequence comparison. Proc Natl Acad Sci USA 85:2444-2448.

Plotsky PM (1991) Pathways to the secretion of adrenocorticotropin: a view from the portal. J Neuroendocrinol 3:1-9.

Plotsky PM, Vale W (1984) Hemorrhage-induced secretion of corticotropin-releasing factor-like immunoreactivity into the rat hypophysial portal circulation and its inhibition by glucocorticoids. Endocrinology 114:164-169.

Plotsky PM, Bruhn TO, Vale W (1985) Evidence for multifactor reg- ulation of the adrenocorticotropin secretory response to hemodynamic stimuli. Endocrinology 116:633-639.

Plotsky PM, Cunningham ET, Widmaier EP (1989) Catecholaminergic modulation of corticotropin-releasing factor and adrenocorticotropin secretion. Endocr Rev 10:437-458.

Ponec J, Lachuer J, Suaud-Chagny MF, Tappaz M (1992) Hemorrhage-induced activations of adrenocorticotropin release and catecholaminc metabolism in the ventrolateral medulla are differently affected by glucocorticoid feedback. J Neuroendocrinol 4:411-420.

Quintin L, Gillon JY, Ghignone M, Renaud B, Pujol JF (1987) Baroreceptor-linked variations of catecholamine metabolism in the caudal ventrolateral medulla: an in vivo electrochemical study. Brain Res 425:319-336.

Rivest S, Rivier C (1991) Influence of the paraventricular nucleus of the hypothalamus in the alteration of neuroendocrine functions induced by intermittent footshock or interleukin. Endocrinology 129: 2049-2057.

Rivest S, Torres G, Rivier C (1992) Differential effects of central and peripheral injection of interleukin- $1 \beta$ on brain c-fos expression and neuroendocrine function. Brain Res 587:13-23.

Rivier C, Vale W (1983) Interaction of corticotropin-releasing factor (CRF) and arginine vasopressin (AVP) on ACTH secretion in vivo. Endocrinology 113:939-942.

Sagar SM, Sharp FR, Curran T (1988) Expression of c-fos protein in brain: metabolic mapping at the cellular level. Science 240:13281331.

Sanger F, Nicklen S, Coulson AR (1977) DNA sequencing with chainterminating inhibitors. Proc Natl Acad Sci USA 74:5463-5467.

Sapolsky R, Rivier C, Yamamoto G, Plotsky P, Vale W (1987) Interleukin- 1 stimulates the secretion of hypothalamic corticotropinreleasing factor. Science 238:522-524.

Sawchenko PE (1987) Adrenalectomy-induced enhancement of CRF and vasopressin immunoreactivity in parvocellular neurosecretory neurons: anatomic, peptide, and steroid specificity. J Neurosci 7:10931106.

Sawchenko PE, Swanson LW (1982) Immunohistochemical identification of neurons in the paraventricular nucleus of the hypothalamus that project to the medulla or to the spinal cord in the rat. J Comp Neurol 205:260-272.

Sawchenko PE, Swanson LW (1990) Organization of CRF immunoreactive cells and fibers in the rat brain: immunohistochemical studies. In: Corticotropin-releasing factor: basic and clinical studies of a neuropeptide (De Souza EB, Nemeroff CB, eds), pp 29-51. Boca Raton, FL: CRC.

Sawchenko PE, Swanson LW, Vale WW (1984) Corticotropin releasing factor: co-expression within distinct subsets of oxytocin-, vasopressin-, and neurotensin-immunoreactive neurons in the hypothalamus of the adult male rat. J Neurosci 4:1118-1129.

Sawchenko PE, Cunningham ET, Mortrud MT, Pfeiffer SW, Gerfen CR (1990) Phaseolus vulgaris leucoagglutinin anterograde axonal transport technique. In: Methods in neurosciences, Vol 3 (Conn PM, ed), pp 247-260. New York: Academic.

Schule R, Rangarajan P, Kliewer S, Ransone LJ, Bolado J, Yang N, Verma IM, Evans RM (1990) Functional antagonism between oncoprotein c-jun and the glucocorticoid receptor. Cell 62:1217-1226.

Seasholtz AF, Thompson RC, Douglass JO (1988) Identification of a cyclic adenosine monophosphate-responsive element in the rat corticotropin-releasing hormone gene. Mol Endocrinol 2:1311-1319.

Simmons DM, Arriza JL, Swanson LW (1989) A complete protocol for in situ hybridization of messenger RNAs in brain and other tissues with radiolabeled single-stranded RNA probes. J Histechnol 12:169181.

Suda T, Tozawa F, Ushiyama T, Sumitomo T, Yamada M, Demura H (1990) Interleukin-1 stimulates corticotropin-releasing factor gene expression in rat hypothalamus. Endocrinology 126:1223-1228.

Swanson LW, Kuypers HGJM (1980) The paraventricular nucleus of the hypothalamus: cytoarchitectonic subdivisions and the organization of projections to the pituitary, dorsal vagal complex and spinal cord as demonstrated by retrograde fluorescence double labeling methods. J Comp Neurol 194:555-570.

Swanson LW, Simmons DM (1989) Differential steroid hormone and neural influences on peptide mRNA levels in CRH cells of the paraventricular nucleus: a hybridization histochemical study in the rat. $\mathrm{J}$ Comp Neurol 285:413-435.

Takahashi H, Nishimura M, Sakamoto M, Ikegaki I, Nakanishi T, 
Yoshimura M (1992) Effects of interleukin 1- $\beta$ on blood pressure, sympathetic nerve activity, and pituitary endocrine functions in anesthetized rats. Am J Hypertens 5:224-229.

Thompson RC, Seasholtz AF, Herbert E (1987) Rat corticotropinreleasing gene: sequence and tissue-specific expression. Mol Endocrinol 1:363-370.

Thompson RC, Seasholtz AF, Douglass JO, Herbert E (1990) Cloning and distribution of expression of the rat corticotropin-releasing(CRF) gene. In: Corticotropin-releasing factor: basic and clinical studies of a neuropeptide (De Souza EB, Nemeroff CB, eds), pp 1-12. Boca Raton, FL: CRC

Watson MA, Milbrandt J (1989) The NGFI-B gene, a transcriptionally inducible member of the steroid receptor gene superfamily: genomic structurc and expression in rat brain after seizure induction. Mol Cell Biol 9:4213-4219.

Watts AG, Swanson LW (1989) The combination of in situ hybridization with immunohistochemistry and retrograde tract-tracing. In
Methods in neurosciences, Vol 1 (Conn PM, ed), pp 127-136. New York: Academic.

Wilson TE, Fahrner TJ, Johnston M, Milbrandt J (1991) Identification of the DNA binding site for NGFI-B by genetic selection in yeast. Science 252:1296-1300.

Wilson TE, Mouw AR, Weaver CA, Milbrandt J, Parker KL (1993) The orphan nuclear receptor NGFI-B regulates expression of the gene encoding steroid 21-hydroxylase. Mol Cell Biol 13:861-868.

Wisden W, Errington ML, Williams S, Dunnett SB, Waters C, Hitchcock D, Evan G, Bliss TVP, Hunt SP (1990) Differential expression of immediate early genes in the hippocampus and spinal cord. Neuron 4:603-614.

Yang-Yen HF, Chambard JC, Sun YL, Smeal T, Schmidt TJ, Drouin J, Karin M (1990) Transcriptional interference between c-jun and the glucocorticoid receptor: mutual inhibition of DNA binding due to direct protein-protein interaction. Cell 62:1205-1215. 